\title{
Trace elements' reference levels in blood of breeding black-browed albatrosses Thalassarche melanophris from the Falkland Islands
}

\author{
Ricardo Furtado $^{1}$ (D) $\cdot$ José Pedro Granadeiro ${ }^{2} \cdot$ Letizia Campioni $^{1} \cdot$ Mónica Silva $^{3} \cdot$ Eduarda Pereira $^{4} \cdot$ Paulo Catry $^{1}$
}

Received: 13 February 2020 / Accepted: 29 June 2020

(C) Springer-Verlag GmbH Germany, part of Springer Nature 2020

\begin{abstract}
Trace elements' concentration in the ocean is fast growing and is a source of major concern. Being charismatic and at the top of food chains, seabirds are often used as biological monitors of contaminants. We studied the concentration of trace elements in blood of black-browed albatross from the Falklands Islands, which we here show, by tracking with geolocators, forage over most of the Patagonian Shelf. Levels of trace elements were measured in males and females from two different islands. Blood concentrations of trace elements were not significantly different between islands, which is consistent with observations from foraging behavior revealing that birds from both islands foraged in broadly the same areas in the months before sampling. Arsenic and selenium concentrations in females were higher than in males. Sex-related differences in the concentration of these elements may be related to unknown slight differences in diet or to differences in assimilation between sexes. These results provide reference values for monitoring elemental contamination in the Patagonian Shelf Large Marine Ecosystem using black-browed albatrosses, one of the most abundant top predators and a suitable sentinel for the region's environmental health.
\end{abstract}

Keywords Thalassarche melanophris $\cdot$ Trace elements $\cdot$ Sex $\cdot$ Foraging behavior $\cdot$ Patagonian shelf

\section{Introduction}

Contamination by trace elements is growing at a fast pace and is an issue of major concern for the health of the environment and organisms (Scheuhammer 1987; Sánchez-Virosta et al. 2015; Evers 2018; Preeti et al. 2018). Plants and animals often

Editorial Responsibility: Philippe Garrigues

Electronic supplementary material The online version of this article (https://doi.org/10.1007/s11356-020-09928-1) contains supplementary material, which is available to authorized users.

Ricardo Furtado

ricardomirandafg@hotmail.com

1 MARE - Marine and Environmental Sciences Centre, ISPA, Instituto Universitário, Lisbon, Portugal

2 CESAM Centre for Environmental and Marine Studies, Departamento de Biologia Animal, Faculdade de Ciências, Universidade de Lisboa, Campo Grande, 1749-016 Lisbon, Portugal

3 Centre for Ecology, Evolution and Environmental Changes, Faculdade de Ciências, Universidade de Lisboa, Lisbon, Portugal

4 Department of Chemistry and CESAM/REQUIMTE, University of Aveiro, 3810-193 Aveiro, Portugal assimilate and bioaccumulate trace elements in a predictable manner, and therefore, some taxa have been successfully used as biological monitors of elemental pollution in marine and terrestrial ecosystems (Anderson et al. 2010; Yildirim and Sasmaz 2017; Furtado et al. 2019).

Several trace elements (cobalt, copper, manganese, selenium, and vanadium) are essential components of physiological and biochemical processes of organisms (e.g., vertebrates), but beyond certain levels of concentration these elements also become toxic (Abdulla and Chmielnicka 1990; Senesi et al. 1999; Bansal and Asthana 2018). Others, such as arsenic, cadmium, mercury, and strontium, are poorly tolerated by the organisms and are usually considered as a non-essential elements for life and are known to be toxic even at low concentration levels (Naidu et al. 1999; Senesi 1999; Bansal and Asthana 2018). Arsenic is considered as one of the most highly toxic and carcinogenic elements by the US Environmental Protection Agency (EPA) (ATSDR 2018).

The Patagonian Shelf Large Marine Ecosystem, in the Southern Ocean, is one of the most productive marine areas worldwide (Croxall and Wood 2002). Here currents and mixing, including localized upwelling, contribute to resuspension of sediments and organic particles, resulting in a natural redistribution of trace elements, notably those behaving like 
nutrients (e.g., copper and selenium) (Orren and Monteiro 1985; Cutter and Cutter 1995; Zhang et al. 2014; Gworek et al. 2016). Elements such as mercury are massively transported by the global atmospheric circulation, and others such as cadmium, cobalt, lead, and manganese are distributed through oceanic circulation. Such inflows to what is present in the Southern Ocean determine the concentration of elements in this marine ecosystem (Chester 1990; Gaiero et al. 2003; Bargagli 2008; Cossa et al. 2011). Moreover, several anthropogenic sources (sewage effluents, agricultural runoff, oil extraction, and transportation and mining) contribute to contamination by metals and metalloids in the ocean, including water and sediments (Gaiero et al. 2002).

The distribution of trace elements in marine waters is complex (Boye et al. 2012). Trace elements are not distributed uniformly in the ocean, and their concentration varies among areas as well as vertically within the water column (Cutter and Cutter 1995; de Villiers 1999; Bown et al. 2011; Cossa et al. 2011; Boye et al. 2012; Heller and Croot 2015; Schlesinger et al. 2017). Such variability in the distribution of trace elements causes different assimilation patterns within food webs (Santos et al. 2006). Moreover, elements such as cadmium, cobalt, copper, manganese, strontium, and vanadium are accumulated by organisms of different trophic levels, but do not biomagnify (even in top predators, such as seabirds) because biodilution processes increase significantly with trophic position (Campbell et al. 2005; Nfon et al. 2009; Revenga et al. 2012; Konovalenko et al. 2016; Liu et al. 2016, 2017, 2019; Signa et al. 2019). Conversely, the extent of arsenic and selenium biomagnification through the food web is a complex issue and is still a matter of scientific debate (Campbell et al. 2005; Mathews and Fisher 2008; Nfon et al. 2009; Stewart et al. 2010; Huang 2016; Furtado et al. 2019). Selenium is transferred in food chains, and biomagnification does occur (Rainbow 2018). Stewart et al. (2010) proposed a "trophic transfer function" to describe increased selenium concentrations in marine food webs, because transfer from prey to predator is dependent on concentration in a non-linear manner. Arsenic, usually in its inorganic forms, decreases with increasing trophic levels, but organic arsenic, especially arsenobetaine, increases (see review Huang 2016). The behavior of mercury is well-known, and it biomagnifies through the food chains, thus, top predators generally show higher mercury levels than primary producers (Santos et al. 2006).

Seabirds are top marine predators known to accumulate a variety of trace elements present in marine environment (Anderson et al. 2010; Tavares et al. 2013; Carravieri et al. 2014, 2018). Those are accumulated in different tissues such as blood, feathers, liver, kidney, and muscle (Anderson et al. 2009; Aazami et al. 2011). Blood has been widely used to assess medium- to short-term variations in element concentrations of trace elements in the environment, reflecting accumulation through diet over approximately 1 to 2 months preceding sampling in seabirds (Hobson and Clark 1992, 1993; Carleton and Martínez del Rio 2005; Zanden et al. 2015). This period varies among taxa according to metabolism, and it can be higher in some other vertebrates such as reptiles (Rosenblatt and Heithaus 2013).

The Falkland Islands are located in the Southwest Atlantic Ocean, where the level of trace elements bioavailability is poorly documented (Furtado et al. 2019). Black-browed albatrosses Thalassarche melanophris from the Falkland Islands mostly forage in the Subantarctic Zone, over the rich waters of the Patagonian Shelf (Granadeiro et al. 2017; Ponchon et al. 2019). Furthermore, birds are relatively sedentary, remaining in the Patagonian shelf and shelf-break also during the non-breeding season (Ponchon et al. 2019). Globally, the species is currently classified as least concern according to the IUCN (2020).

The levels of bioaccumulation of trace elements are important indicators of environmental quality and health of seabirds (Nicholson and Osborn 1983; Anderson et al. 2010; SánchezVirosta et al. 2015; Evers 2018). Seabirds are generally abundant at their nesting colonies, forage over wide oceanic areas, are often easy to capture, and can be sampled with minimal disturbance. Blood is a good tissue to monitor levels of several trace elements over the Patagonian Shelf Large Marine Ecosystems during the breeding season. An estimated 67.0 $70.0 \%$ of the global population of this albatross species nests in the Falkland Island (ACAP 2009), with a total population in excess of 475,500 pairs (Wolfaardt 2013). Being well-known charismatic top predators in Patagonian Shelf ecosystem, black-browed albatrosses have the potential to be used as biological monitors and to communicate environmental issues to decision-makers and the general public.

The goal of this research was to establish baseline levels of trace elements in blood of black-browed albatrosses, as samplers of the Patagonian Shelf Large Marine Ecosystem, during the breeding period. We determined trace elements concentrations in blood samples of birds from Beauchene and New Island, two islands located in the South and West of the Falkland Islands, respectively, roughly reflecting accumulation between October and December 2016. We also assessed the spatial distribution of birds from both islands during this period. Finally, we tested whether there were differences in the accumulation of trace elements among sexes, as found in other waterbirds and in albatrosses for cadmium (e.g., Carravieri et al. 2014), mercury (e.g., Tavares et al. 2013), and selenium (e.g., Wilson et al. 2004).

\section{Methods}

\section{Study sites and trace elements concentration survey}

Blood sampling was carried out during December 2016 and early January 2017. We collected a small amount of blood (< 
$2.0 \mathrm{ml}$ ) from 20 adult black-browed albatrosses breeding on New Island $\left(51^{\circ} 43^{\prime} \mathrm{S}, 61^{\circ} 19^{\prime} \mathrm{W}\right)$ and 18 birds from Beauchene Island $\left(52^{\circ} 50^{\prime} \mathrm{S}, 59^{\circ} 10^{\prime} \mathrm{W}\right)$. We took a small aliquot of each sample into a different container for sex determination using molecular methods. The sampling procedure took less than 5 min to complete, and all birds resumed their incubation and brooding duties after being released at the nest.

Samples for elements determination were lyophilized during $48 \mathrm{~h}$ and ground to powder for homogenization, before digestion. All samples were digested following an adaptation of the EPA method 3051A (Link et al. 1998). Blood samples were digested using a CEM MARS 5, model 240/50 microwave digestion system, with continuous temperature and pressure monitoring in a tightly closed vessel. Closed vessels also minimize potential losses of analytes due to volatilization (Link et al. 1998). Previously, PFA vessels were decontaminated in the microwave system using $3.0 \mathrm{ml}$ of $\mathrm{HNO}_{3}$ and then rinsed with ultrapure water and air-dried. Approximately $50.0 \mathrm{mg}$ (overall range: $4.1-190.3 \mathrm{mg}$ ) of sample were weighted in PFA digestion vessels, and subsequently, we added $0.4 \mathrm{~mL}$ of nitric acid $\left(\mathrm{HNO}_{3}\right)$. The microwave was programmed for $5 \mathrm{~min}$, at $1600 \mathrm{~W}$ and $165^{\circ} \mathrm{C}$, followed by $5 \mathrm{~min}$ at $1600 \mathrm{~W}$ and $190{ }^{\circ} \mathrm{C}$. The PFA vessels were then placed in a plate heater, and the contents evaporated to near dryness at $150{ }^{\circ} \mathrm{C}$. Finally, the residue was dissolved in $0.4 \mathrm{~mL}$ of hydrogen peroxide $\left(\mathrm{H}_{2} \mathrm{O}_{2}\right)$, and the solutions heated for $30 \mathrm{~min}$, at $150{ }^{\circ} \mathrm{C}$. After cooling at room temperature, the solutions were transferred into 10.0-mL volumetric flasks and then filled with ultrapure water (MQ filtration system) to the $10.0 \mathrm{~mL}$ and then analyzed by high resolution ICP-MS (Thermo Elemental, X-Series). The experimental conditions for ICP-MS analysis were as follows: forward power $1400 \mathrm{~W}$, peak jumping mode, 150 sweeps per replicate, dwell time $10 \mathrm{~min}$, and dead time $30 \mathrm{~min}$. The polyatomic and isobaric interferences were minimized by setting the ratios ${ }^{137} \mathrm{Ba}^{2+} /{ }^{137} \mathrm{Ba}$ and ${ }^{140} \mathrm{Ce}^{16} \mathrm{O} /{ }^{140} \mathrm{Ce}$ to 0.02 , under routine operating conditions. The internal standard was ${ }^{115} \mathrm{In}$. For quality control, the certified reference material NIST-SRM 2976 (mussel tissue) and TORT-2 (lobster hepatopancreas) were analyzed simultaneously (see results in Supplementary Table A1).

Among trace elements, arsenic, mercury, selenium, and strontium were quantified in all individuals, while cadmium, cobalt, manganese, and vanadium could only be detected in a few black-browed albatrosses. The limit of quantification (LoQ), was calculated as ten times the standard deviation (SD) of the blank divided by the slope of the analytical curve, respectively (Taleuzzaman 2018), expressed in concentration $(\mu \mathrm{g} / \mathrm{L})$. The limit of quantification was converted to $\mathrm{mg} / \mathrm{kg}$ dry weight per sample (Supplementary Table A2 and Supplementary Table A3).

\section{Sex determination}

Black-browed albatrosses exhibit a clear sexual dimorphism in some behaviors, and in the present work, 12 birds were sexed by direct observation of the pair during the pre-laying period. Whenever this was not possible, we used the molecular-based method described in Fridolfsson and Ellegren (1999) using DNA extracted from blood samples $(n=26)$.

\section{Geolocation data}

In order to obtain information on the areas used by albatrosses prior to the collection of our samples, we deployed legmounted Mk19 light-level geolocators (GLS) on 20 adult black-browed albatrosses on Beauchene Island in December 2015, which were then recovered in January 2017. Of these, 12 loggers delivered usable data. Positions were obtained from light information analyzed following the method employed by Dias et al. (2011) and Phillips et al. (2004). GLS data of black-browed albatross from New Island were not available for 2016, and therefore, we used GLS information from 7 adult birds collected in 2013. GLS positions obtained between October and December (e.g., 3 months prior to sample collection) were examined using kernel density estimate (KDE) analysis, which were used to depict $50.0 \%$, $75.0 \%$, and $90.0 \%$ of density contour areas (the estimated foraging range). All calculations were carried out with the adehabitatHR package (Calenge 2006) running in $\mathrm{R}$ (R Core Team 2019).

\section{Data analysis}

Trace elements levels with concentrations lower than limit of quantification in more than $50 \%$ of the individuals, which included cadmium, cobalt, manganese, and vanadium, were excluded from subsequent statistical analyses (e.g., Anderson et al. 2010). The effects of island and sex in levels of trace elements were evaluated by two-way ANOVAs, after checking for data normality. Covariance models (ANCOVA) were used to test the effect of sex in the correlations between trace elements concentrations. Means are presented with standard deviations.

\section{Results}

\section{Concentration of trace elements in blood}

Levels of arsenic, cadmium, cobalt, copper, manganese, mercury, selenium, strontium, and vanadium in blood of blackbrowed albatross are shown in Table 1 . 


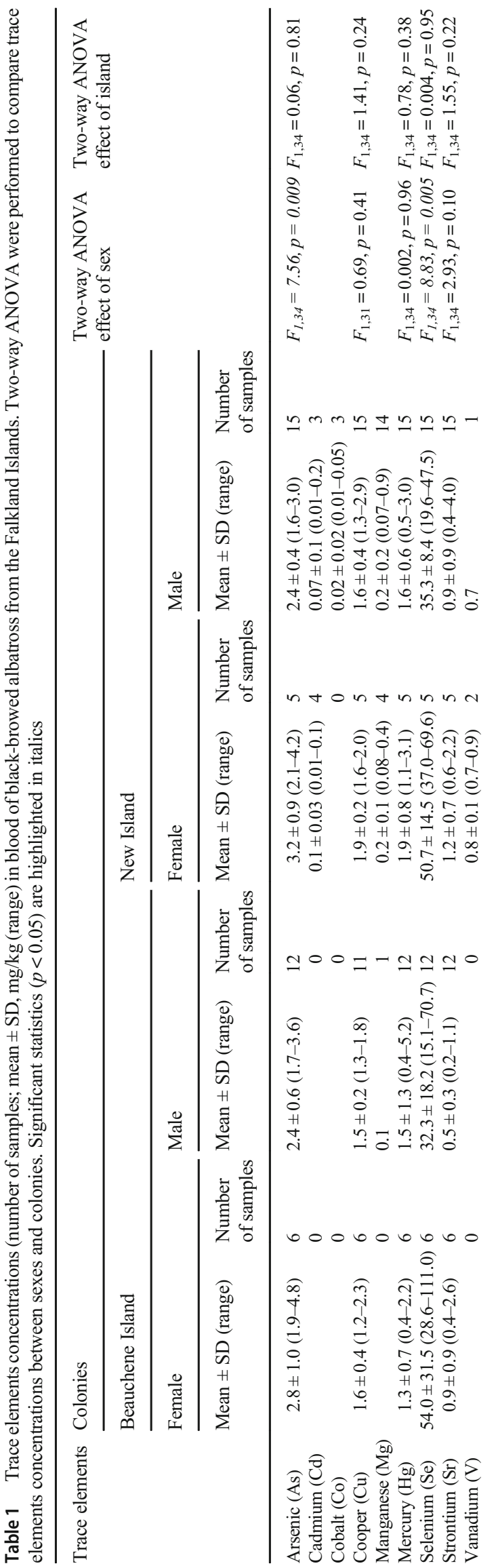

We did not find any differences between islands in any of the trace elements analyzed. Conversely, there were significant differences between sexes (Fig. 2) in the concentrations of arsenic (two-way ANOVA, effect of sex: $F_{1,34}=7.56, p=$ $0.009)$ and selenium $\left(F_{1,34}=8.83, p=0.005\right)$, with males showing lower concentrations than females (arsenic: females: $3.02 \pm 0.97 \mathrm{mg} / \mathrm{kg}$, males: $2.37 \pm 0.49 \mathrm{mg} / \mathrm{kg}$; selenium: females: $52.50 \pm 24.13 \mathrm{mg} / \mathrm{kg}$, males: $33.94 \pm 13.43 \mathrm{mg} / \mathrm{kg}$ ).

The analysis of covariance showed a significant correlation between the levels of selenium and arsenic $\left(F_{1,35}=99.5\right.$, $p<0.001)$, but there was no effect of $\operatorname{sex}\left(F_{1,35}=1.46, p=\right.$ $0.234)$. The same was observed in the relationship between copper and strontium $\left(F_{1,34}=61.5, p<0.001\right.$, no effect of sex, $\left.F_{1,34}=0.48, p=0.496\right)$ and selenium and copper $\left(F_{1,34}=\right.$ $4.67, p=0.038$, no effect of sex, $F_{1,34}=0.03, p=0.864$ ).

The analysis of covariance revealed differences among sexes in the correlation between arsenic and copper $\left(F_{1,34}=\right.$ 4.40, $p=0.043$ ), with concentrations of arsenic in females being ca. $0.6 \mathrm{mg} / \mathrm{kg}$ higher than in males, for the same values of copper $\left(F_{1,34}=6.81, p=0.013\right)$. The same was observed for the relationship between selenium and mercury $\left(F_{1,35}=\right.$ $5.62, p=0.023$ ), with concentrations of selenium in females being ca. $18.6 \mathrm{mg} / \mathrm{kg}$ higher than in males for the same values of mercury $\left(F_{1,35}=10.52, p=0.003\right)$.

\section{Discussion}

Birds tracked in this study carried out foraging trips within the Patagonian shelf. More specifically, kernel density distributions of black-browed albatrosses from New Island and Beauchene Island (islands located $200 \mathrm{~km}$ apart) revealed no major differences in the areas of the Patagonian Shelf used between October and December (Fig. 1). Despite the high overlap between the kernels (ca. 62.0\%), birds from New Island also seem to be using an area slightly more to the north than the one used by those from Beauchene Island.

The levels of trace elements measured in black-browed albatross blood in those two different islands should be indicative of contamination in this broad Patagonian Shelf region (Table 1). The mean concentration of trace elements decreased in the following order: selenium $>$ arsenic $>$ copper $>$ mercury $>$ strontium $>$ vanadium $>$ manganese $>$ cadmium $>$ cobalt . Levels of contaminants in the Falkland Islands were generally low when compared with data from other species and locations in the Southern Ocean. Arsenic was the exception, as birds from the Falkland Islands showed comparatively high concentrations of this element (Supplementary Table A4).

We did not find any difference between islands in the levels of arsenic, copper, mercury, selenium, and strontium in the blood of albatrosses (Table 1), which fits well with the large overlap in foraging areas of birds from the two colonies. The diet of albatross from New Island are broadly composed of 

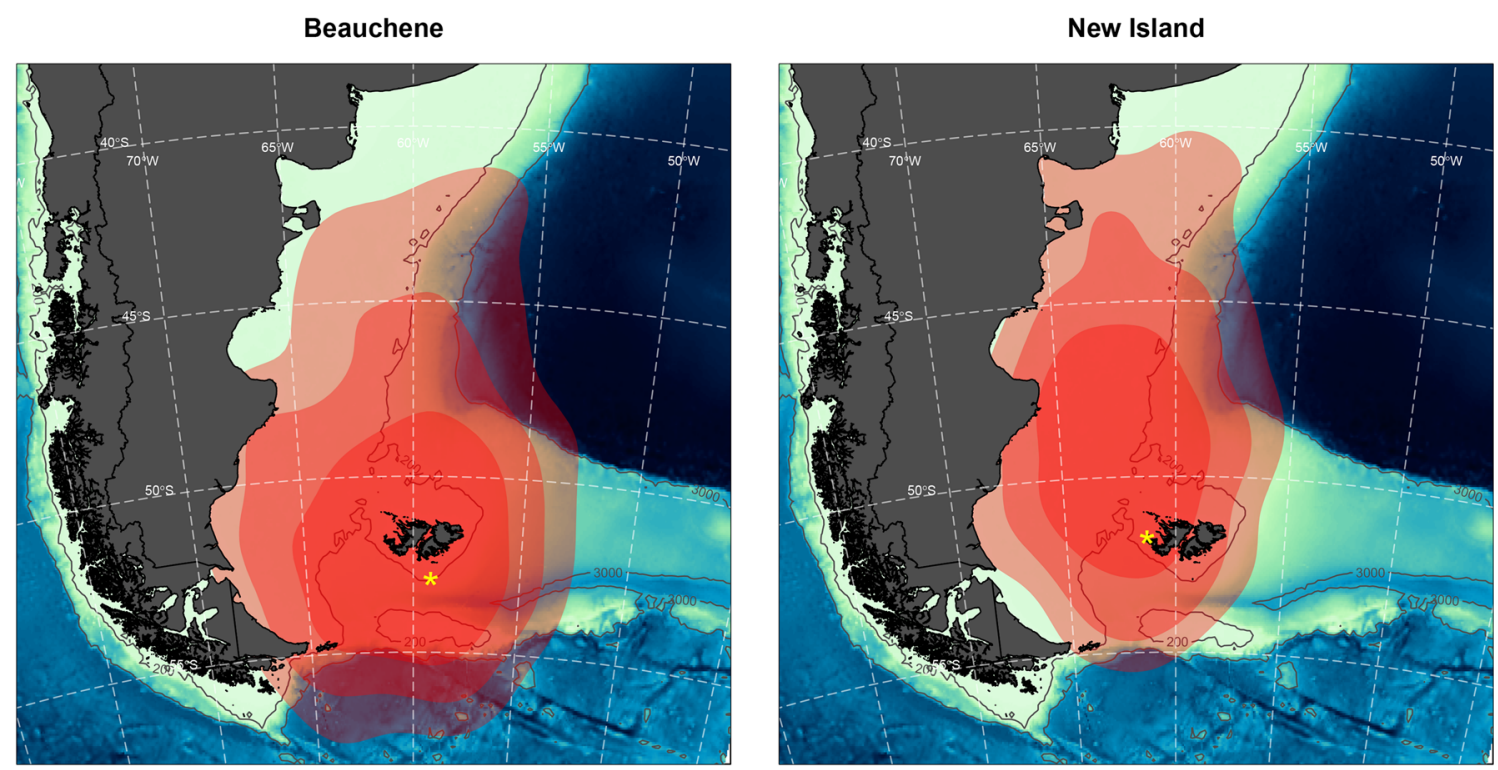

Fig. 1 Kernel density estimates of Black-browed albatrosses (BBA) successfully tagged with geolocators at Beauchene $(2016, N=12)$ and New Island $(2013, N=7)$ between October and December (incubation-early chick-rearing). Colors represent 50\%, 75\%, and $90 \%$ contours

fish (mostly Sprattus fuegensis and Patagonotothen sp.), Crustacea (mostly lobster krill Munida gregaria), and Scyphozoa (e.g., jellyfish) (McInnes et al. 2017a, b), and Thompson (1992) reported the same groups of prey for albatrosses from Beauchene Island, which again concurs with a high overlap in feeding areas and similar levels of contamination. Furtado et al. (2019) reported no significant differences in mercury levels in feathers of black-browed albatross between New Island and Beauchene Island.

In the ocean, arsenic, cadmium, copper, mercury, selenium, and strontium occur in lower concentrations at the surface $(<$ $100 \mathrm{~m}$ ) than in deeper waters (Westerlund and Ghman 1991; Cutter and Cutter 1995; de Villiers 1999; Cutter et al. 2001; Heller and Croot 2015). Methylmercury concentration increases with depth to an intermediate maximum in the mesopelagic domain (Cossa et al. 2011). The concentration of copper, mercury, and strontium appears to be higher in the Antarctic waters than in the other oceanic areas (Cossa et al. 2011; de Villiers 1999; Heller and Croot 2015). Furthermore, Antarctic Intermediate Waters exhibit some of the highest arsenic concentration observed in the ocean (Santosa et al. 1994; Cutter et al. 2001). For example, Euphausia superba, a commonly found prey in the diet of black-browed albatross from South Georgia, has $5.5 \pm 1.1 \mathrm{mg} / \mathrm{kg}$ of selenium and $0.01 \pm 0.01 \mathrm{mg} / \mathrm{kg}$ of mercury (Anderson et al. 2009, 2010). Recently, Sontag et al. (2019) reported concentration of methylmercury between 0.00074 to $0.00294 \mathrm{mg} / \mathrm{kg}$ and 0.00026 to $0.00161 \mathrm{mg} / \mathrm{kg}$ in juvenile and adult Euphausia superba respectively. Besides contrasting levels of background contamination, differences in the food web structure may help explain the higher concentrations of several trace elements in black-browed albatrosses in South Georgia, compared with the Falkland Islands (Supplementary Table A4). In the former region, albatrosses forage mostly over deep oceanic waters (e.g., Wakefield et al. 2012) and will have a different exposure compared with those foraging around the Falkland Islands, where the birds forage almost exclusively over shallower environments on the shelf (e.g., Granadeiro et al. 2017; Ponchon et al. 2019).

The concentration of arsenic and selenium was significantly higher in females than in males (Fig. 2, Table 1). Males and females black-browed albatrosses from the Falklands show similar foraging areas year-round and particularly during October-December (Ponchon et al. 2019; own unpublished data). Furthermore, they seem to have similar diets as assessed by nitrogen and carbon stable isotopes (Campioni et al. 2016). Hence, one could expect that element levels would be lower for females than males, because females have the possibility to eliminate some contaminants through excretion in eggs (Monteiro and Furness 1995; Kubota et al. 2002; Ackerman et al. 2016). However, arsenic and selenium levels were higher in females than in males, suggesting that maternal transfer of these elements to the egg may be limited in this species. Metabolic differences between sexes and/or different assimilation rates may explain the lower levels of arsenic and selenium found in males. There have been previous studies that reported lower levels of arsenic, mercury, and selenium in males than females (Becker et al. 2002; González-Solís et al. 2002; Wilson et al. 2004; Taggart et al. 2006; Lucia et al. 2010; Carvalho et al. 2013; Tavares et al. 2013; Carravieri et al. 2014; Ackerman et al. 2016). However, this pattern is dependent on the species of birds and/or location. Bustamante 

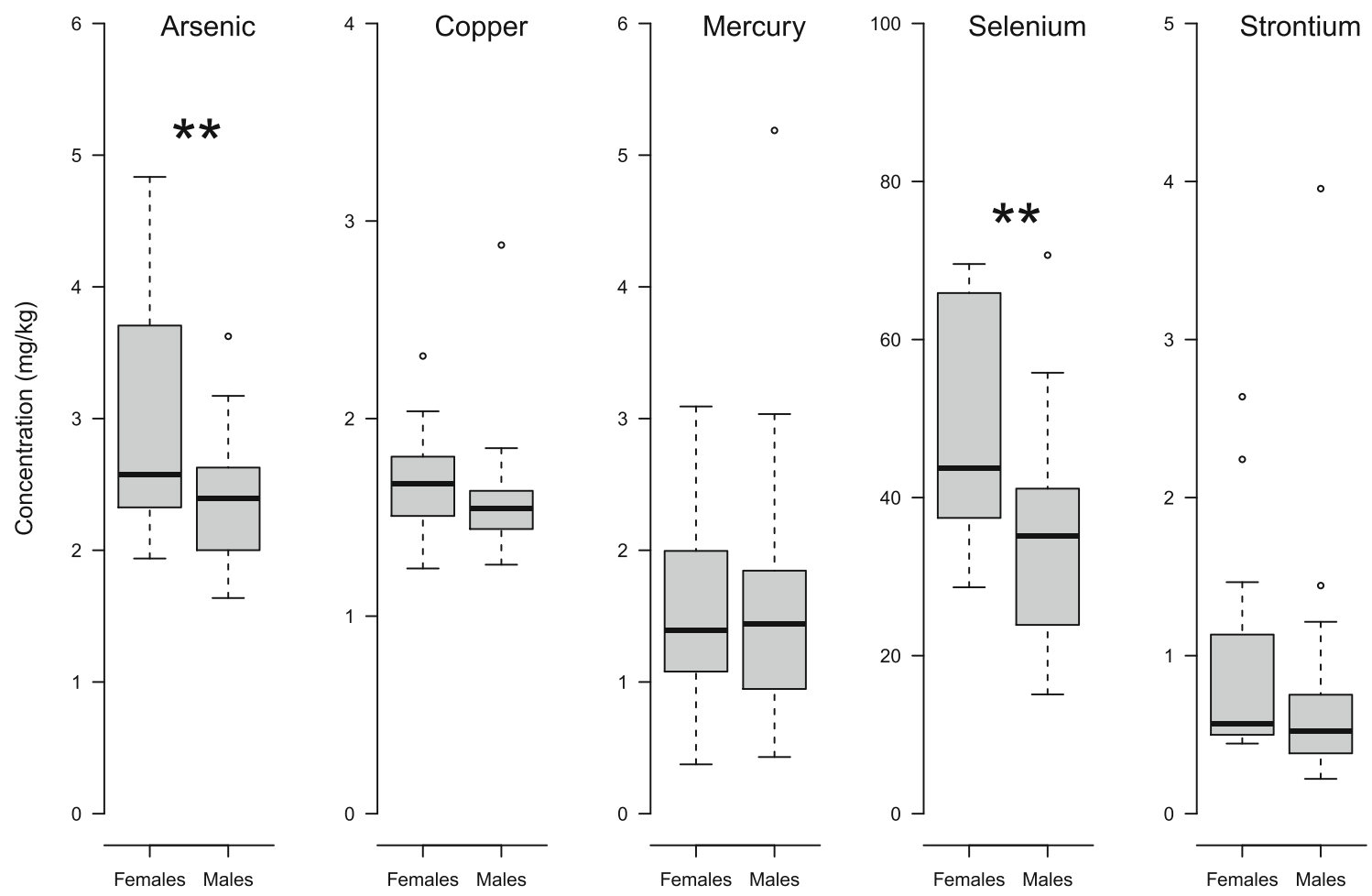

Fig. 2 Black-browed albatross blood concentrations ( $\mathrm{mg} / \mathrm{kg}$ ) of five trace elements (arsenic, copper, mercury, selenium, and strontium) grouped by Sex

shows the inter-quartile range (25-75th percentile), the bold line is the median, the whiskers represent maximum and minimum, and (when present) dots indicate outliers

et al. (2016) have reported a difference in mercury, between female and male wandering albatrosses Diomedea exulans from South Georgia and suggested that maternal transfer of mercury to the egg was limited in this species. Pon et al. (2011) and Tavares et al. (2013) have reported no effect of sex in cadmium, cooper, and mercury in feathers of albatrosses. However, the significance of the presence of elements such as cadmium in feathers is more difficult to assess, as cadmium does not seem to integrate this biological matrix in response to exposure levels.

We found a positive correlation between levels of mercury and of selenium in blood of black-browed albatrosses. This relationship is important, since selenium interacts with mercury to form inert complexes of high molecular weight in the blood, especially in the erythrocytes, and forms harmless nondiffusible complexes (mercury-selenium) in the liver and kidney and therefore acts as a form of protection against methylmercury toxicity (thus delivering a "detoxifying" effect for methylmercury) (Cuvin-Aralar and Furness 1991; Imura and Naganuma 1991; Yang et al. 2008). Some researchers have reported that mercury concentrations in the feathers, liver, and kidney of birds between 5 and $40 \mathrm{mg} / \mathrm{kg}$ can have negative impacts expressed by changes in reproduction and survival (Wolfe et al. 1998; Evers et al. 2008; Whitney and Cristol 2017). Overall, mercury levels in blood of black-browed albatross analyzed in this study are below the $5 \mathrm{mg} / \mathrm{kg}$ threshold in $97 \%$ of the individuals sampled $(n=38)$, and the highest value recorded in our sample was $5.19 \mathrm{mg} / \mathrm{kg}$. Most researchers investigating relationships between blood mercury and breeding and/or survival have found no suggestion for an impact of mercury in seabirds, which may indicate that seabirds exhibit extraordinary resistance to contamination (Goutte et al. 2014, 2015; Pollet et al. 2017; Bond et al. 2015; Tartu et al. 2016; Carravieri et al. 2018).

In our albatross samples, copper was correlated with strontium, arsenic, and selenium and arsenic with selenium. Recent research suggests selenium antagonizes the toxicity of arsenic mainly through sequestration of this element into biologically inert arsenic - selenium compounds and/or through increasing the arsenic methylation capacity in the body (decreased tissue accumulation of arsenics and its toxic effects) in diverse organs and tissues (see review Zwolak 2020). These correlations between elements suggests an interaction between elements in the blood or, alternatively, an assimilation from a common source of pollution (e.g., foraging area or type of prey), but further research is required to unveil the mechanisms behind such relationships.

We also highlight that our study presents the first baseline data on the concentrations of cobalt in blood of black-browed albatross. 


\section{Conclusion}

This study establishes baseline levels for nine trace elements in black-browed albatross of the Falkland Islands that will be useful for future monitoring under a scenario of rapid changes in the ocean biogeochemistry (Geibert 2018). Albatrosses from Falkland Islands are exposed to low-to-moderate concentrations of trace elements, as compared with other islands and species in the Southern Ocean (Supplementary Table A4). Results of trace element concentrations suggest that birds from different Falkland colonies are exposed to the same background levels, which reflects the large overlap in foraging areas. The concentrations of arsenic and selenium varied with sex, despite the fact that the foraging areas of males and females show almost complete overlap (Ponchon et al. 2019; own unpublished data). Potential differences between sexes in diet and physiology deserve further investigation.

Acknowledgments We are grateful to all the fieldworkers who assisted us with this research. Many thanks to the New Island Conservation Trust, who supported field studies on their New Island reserve.

Funding information Thanks are due to FCT/MCTES for the financial support to CESAM (UIDP/50017/2020+UIDB/50017/2020) and MARE (UIDB/04292/2020 and UIDP/04292/2020), through national funds. Formal permits and further financial support were received from the Falkland Islands Government and the Environmental Studies Budget.

\section{Compliance with ethical standards}

Conflict of interest The authors declare that they have no conflict of interest.

\section{References}

Aazami J, Esmaili-Sari A, Bahramifar N, et al (2011) Mercury in liver, kidney, feather and muscle of seabirds from major wetlands of the Caspian Sea, Iran. Bull Environ Contam Toxicol 86:657-661. https://doi.org/10.1007/s00128-011-0271-6

Abdulla M, Chmielnicka J (1990) New aspects on the distribution and metabolism of essential trace elements after dietary exposure to toxic metals. Biol Trace Elem Res 23:25-53

ACAP (2009) ACAP Species Assessment: black-browed albatross Thalassarche melanophris. http://www.acap.aq. Accessed on $1 \mathrm{Sept}$

Ackerman JT, Eagles-smith CA, Herzog MP, Hartman CA (2016) Maternal transfer of contaminants in birds: mercury and selenium concentrations in parents and their eggs. Environ Pollut 210:145154. https://doi.org/10.1016/j.envpol.2015.12.016

Anderson ORJ, Phillips RA, McDonald RA et al (2009) Influence of trophic position and foraging range on mercury levels within a seabird community. Mar Ecol Prog Ser 375:277-288. https://doi.org/ 10.3354/meps07784

Anderson ORJ, Phillips RA, Shore RF et al (2010) Element patterns in albatrosses and petrels: Influence of trophic position, foraging range, and prey type. Environ Pollut 158:98-107. https://doi.org/10.1016/j. envpol.2009.07.040

ATSDR, Agency for Toxic Substances and Disease Registry (2018). URL http://www.atsdr.cdc.gov/substances/ toxsubstance.asp?toxid $\backslash$ protect $\$ \backslash$ relax $\backslash$ protect $\{\backslash$ begingroup $1 \backslash$ endgroup @@over4\}\$3. Accessed on 05 Apr 2020

Bansal SL, Asthana S (2018) Biologically essential and non-essential elements eausing toxicity in environment. J Environ Anal Toxicol. https://doi.org/10.4172/2161-0525.1000557

Bargagli R (2008) Environmental contamination in Antarctic ecosystems. Sci Total Environ 400:212-226. https://doi.org/10.1016/j.scitotenv. 2008.06.062

Becker PH, González-Solís J, Behrends B, Croxall JP (2002) Feather mercury levels in seabirds at South Georgia: influences of trophic position, sex and age. Mar Ecol Prog Ser 243:261-269. https://doi. org/10.3354/meps243261

Bond AL, Hobson KA, Branfireun BA (2015) Rapidly increasing methyl mercury in endangered ivory gull (Pagophila eburnea) feathers over a 130 year record. Proc R Soc Lond B Biol Sci 282:20150032

Bown J, Boye M, Baker A et al (2011) The biogeochemical cycle of dissolved cobalt in the Atlantic and the Southern Ocean south off the coast of South Africa. Mar Chem 126:193-206. https://doi.org/ 10.1016/j.marchem.2011.03.008

Boye M, Wake BD, Garcia PL et al (2012) Distributions of dissolved trace metals $(\mathrm{Cd}, \mathrm{Cu}, \mathrm{Mn}, \mathrm{Pb}, \mathrm{Ag})$ in the southeastern Atlantic and the Southern Ocean. Biogeosciences 9:3231-3246. https://doi.org/ 10.5194/bg-9-3231-2012

Bustamante P, Carravieri A, Goutte A et al (2016) High feather mercury concentrations in the wandering albatross are related to sex, breeding status and trophic ecology with no demographic consequences. Environ Res 144:1-10. https://doi.org/10.1016/j.envres.2015.10. 024

Calenge C (2006) The package "adehabitat" for the R software: A tool for the analysis of space and habitat use by animals. Ecological Modelling 197 (3-4):516-519

Campbell LM, Norstrom RJ, Hobson KA et al (2005) Mercury and other trace elements in a pelagic Arctic marine food web (Northwater Polynya, Baffin Bay). Sci Total Environ 351-352:247-263. https://doi.org/10.1016/j.scitotenv.2005.02.043

Campioni L, Granadeiro P, Catry P (2016) Niche segregation between immature and adult seabirds: does progressive maturation play a role? Behav Ecol 27:426-433. https://doi.org/10.1093/beheco/ arv167

Carleton SA, Martínez del Rio C (2005) The effect of cold-induced increased metabolic rate on the rate of ${ }^{13} \mathrm{C}$ and ${ }^{15} \mathrm{~N}$ incorporation in house sparrows (Passer domesticus). Oecologia 144:226-232. https://doi.org/10.1007/s00442-005-0066-8

Carravieri A, Bustamante P, Tartu S et al (2014) Wandering albatrosses document latitudinal variations in the transfer of persistent organic pollutants and mercury to Southern Ocean predators. Environ Sci Technol 48:14746-14755

Carravieri A, Fort J, Tarroux A et al (2018) Mercury exposure and shortterm consequences on physiology and reproduction in Antarctic petrels. Environ Pollut. https://doi.org/10.1016/j.envpol.2017.11. 004

Carvalho PC, Bugoni L, McGill RAR, Bianchini A (2013) Metal and selenium concentrations in blood and feathers of petrels of the genus procellaria. Environ Toxicol Chem 32:1641-1648. https://doi.org/ 10.1002/etc.2204

Chester R (1990) Trace elements in the oceans. In: Marine Geochemistry. pp 346-421

Cossa D, Heimbu L, Lannuzel D et al (2011) Mercury in the Southern Ocean. Geochim Cosmochim Acta 75:4037-4052. https://doi.org/ 10.1016/j.gca.2011.05.001

Croxall JP, Wood AG (2002) The importance of the Patagonian Shelf for top predator species breeding at South Georgia. Aquat Conserv 12: $101-118$

Cutter GA, Cutter LS (1995) Behavior of dissolved antimony, arsenic, and selenium in the Atlantic Ocean. Mar Chem 49:295-306. https:// doi.org/10.1016/0304-4203(95)00019-N 
Cutter GA, Cutter LS, Featherstone AM, Lohrenz SE (2001) Antimony and arsenic biogeochemistry in the western Atlantic Ocean. Deep Res Part II Top Stud Oceanogr 48:2895-2915. https://doi.org/10. 1016/S0967-0645(01)00023-6

Cuvin-Aralar MLA, Furness RW (1991) Mercury and selenium interaction: A review. Ecotoxicol Environ Saf 21:348-364. https://doi.org/ 10.1016/0147-6513(91)90074-Y

de Villiers S (1999) Seawater strontium and $\mathrm{Sr} / \mathrm{Ca}$ variability in the Atlantic and Pacific oceans. Earth Planet Sci Lett 171:623-634

Dias MP, Granadeiro JP, Phillips RA et al (2011) Breaking the routine: Individual Cory's shearwaters shift winter destinations between hemispheres and across ocean basins. Proc R Soc B Biol Sci 278: 1786-1793

Evers D (2018) The effects of methylmercury on wildlife: a comprehensive review and approach for interpretation. Elsevier Inc.

Evers DC, Savoy LJ, Desorbo CR et al (2008) Adverse effects from environmental mercury loads on breeding common loons. Ecotoxicology 17:69-81. https://doi.org/10.1007/s10646-0070168-7

Fridolfsson AK, Ellegren H (1999) A simple and universal method for molecular sexing of non-ratite birds. J Avian Biol 30:116-121

Furtado R, Pereira ME, Granadeiro JP, Catry P (2019) Body feather mercury and arsenic concentrations in five species of seabirds from the Falkland Islands. Mar Pollut Bull. https://doi.org/10.1016/j. marpolbul.2019.110574

Gaiero DM, Probst JL, Depetris PJ et al (2002) Riverine transfer of heavy metals from Patagonia to the southwestern Atlantic Ocean. J Mater Cycles Waste Manag 3:51-64. https://doi.org/10.1007/s10113-0010040-x

Gaiero DM, Probst JL, Depetris PJ et al (2003) Iron and other transition metals in Patagonian riverborne and windborne materials: geochemical control and transport to the southern South Atlantic Ocean. Geochim Cosmochim Acta 67:3603-3623. https://doi.org/10. 1016/S0016-7037(03)00211-4

Geibert W (2018) Processes that regulate trace element distribution in the ocean. Elements 14:391-396. https://doi.org/10.2138/gselements. 14.6.391

González-solís J, Sanpera C, Ruiz X (2002) Metals and selenium as bioindicators of geographic and trophic segregation in giant petrels. Mar Ecol Prog Ser 244:257-264

Goutte A, Bustamante P, Barbraud C et al (2014) Demographic responses to mercury exposure in two closely-related Antarctic top predators. Ecology 95:1075-1086

Goutte A, Barbraud C, Herzke D et al (2015) Survival rate and breeding outputs in a high Arctic seabird exposed to legacy persistent organic pollutants and mercury. Environ Pollut 200:1-9. https://doi.org/10. 1016/j.envpol.2015.01.033

Granadeiro JP, Campioni L, Catry P (2017) Albatrosses bathe before departing on a foraging trip: implications for risk assessments and marine spatial planning. Bird Conserv Int 17:32-35. https://doi.org/ 10.1186/s40462-016-0093-6

Gworek B, Bemowska-Kałabun O, Kijeńska M, Wrzosek-Jakubowska J (2016) Mercury in Marine and Oceanic Waters - a review. Water Air Soil Pollut. https://doi.org/10.1007/s11270-016-3060-3

Heller MI, Croot PL (2015) Copper speciation and distribution in the Atlantic sector of the Southern Ocean. Mar Chem 173:253-268. https://doi.org/10.1016/j.marchem.2014.09.017

Hobson KA, Clark RG (1992) Assessing avian diets using stable isotopes I: Turnover of ${ }^{13} \mathrm{C}$ in tissues. Condor 94:189-197. https://doi.org/10. $2307 / 1368808$

Hobson K, Clark RC (1993) Turnover of ${ }^{13} \mathrm{C}$ in cellular and plasma fractions of blood: implications for nondestructive sampling in avian dietary studies. Auk 110:638-641

Huang J (2016) Arsenic trophodynamics along the food chains/webs of different ecosystems: a review. Chem Ecol 32:803-828. https://doi. org/10.1080/02757540.2016.1201079
Imura N, Naganuma A (1991) Possible mechanism of detoxifying effect of selenium on the toxicity of mercury compounds. Adv Mercur Toxicol:275-288

IUCN (2020) IUCN red list of threatened species. URL http://www. iucnredlist.org. Accessed 1 Apr 2020

Konovalenko L, Bradshaw C, Andersson E et al (2016) Evaluation of factors influencing accumulation of stable $\mathrm{Sr}$ and $\mathrm{Cs}$ in lake and coastal fish. J Environ Radioact 160:64-79. https://doi.org/10. 1016/j.jenvrad.2016.04.022

Kubota R, Kunito T, Tanabe S et al (2002) Maternal transfer of arsenic to eggs of black-tailed gull (Larus crassirostris) from Rishiri Island, Japan. Appl Organomet Chem 16:463-468. https://doi.org/10.1002/ aoc. 322

Link DD, Walter PJ, Kingston HM (1998) Development and validation of the new EPA Microwave-Assisted Leach Method 3051A. Environ Sci Technol 32:3628-3632. https://doi.org/10.1021/ es980559n

Liu Y, Zhou Q, Xu J et al (2016) Assessment of total and organic vanadium levels and their bioaccumulation in edible sea cucumbers: tissues distribution, inter-species-specific, locational differences and seasonal variations. Environ Geochem Health 38:111-122. https://doi.org/10.1007/s10653-015-9689-9

Liu Y, Liu G, Yuan Z et al (2017) Presence of arsenic, mercury and vanadium in aquatic organisms of Laizhou Bay and their potential health risk. Mar Pollut Bull 125:334-340. https://doi.org/10.1016/j. marpolbul.2017.09.045

Liu J, Cao L, Dou S (2019) Trophic transfer, biomagnification and risk assessments of four common heavy metals in the food web of Laizhou Bay, the Bohai Sea. Sci Total Environ 670:508-522. https://doi.org/10.1016/j.scitotenv.2019.03.140

Lucia M, André JM, Gontier K et al (2010) Trace element concentrations (mercury, cadmium, copper, zinc, lead, aluminium, nickel, arsenic, and selenium) in some aquatic birds of the southwest atlantic coast of France. Arch Environ Contam Toxicol 58:844-853. https://doi. org/10.1007/s00244-009-9393-9

Mathews T, Fisher NS (2008) Trophic transfer of seven trace metals in a four-step marine food chain. Mar Ecol Prog Ser 367:23-33. https:// doi.org/10.3354/meps07536

McInnes JC, Alderman R, Lea M et al (2017a) High occurrence of jellyfish predation by black-browed and Campbell albatross identified by DNA metabarcoding. Mol Ecol:1-15. https://doi.org/10.1111/mec. 14245

McInnes JC, Jarman SN, Lea M et al (2017b) DNA metabarcoding as a marine conservation and management tool: a circumpolar examination of fishery discards in the diet of threatened albatrosses. Front Mar Sci 4:277. https://doi.org/10.3389/fmars.2017.00277

Monteiro LR, Furness RW (1995) Seabirds as monitors of mercury in the marine environment. Water Air Soil 80:851-870

Naidu GRK, Denschlag HO, Mauerhofer E et al (1999) Determination of macro, micro nutrient and trace element concentrations in Indian medicinal and vegetable leaves using instrumental neutron activation analysis. Appl Radiat Isot 50:947-953. https://doi.org/10.1016/ S0969-8043(98)00113-4

Nfon E, Cousins IT, Järvinen O et al (2009) Trophodynamics of mercury and other trace elements in a pelagic food chain from the Baltic Sea. Sci Total Environ 407:6267-6274. https://doi.org/10.1016/j. scitotenv.2009.08.032

Nicholson JK, Osborn D (1983) Kidney lesions in pelagic seabirds with high tissue levels of cadmium and mercury. J Zool 200:99-118. https://doi.org/10.1111/j.1469-7998.1983.tb06111.x

Orren MJ, Monteiro PMS (1985) Trace element geochemistry in the Southern Ocean. Antarct Nutr cycles food webs 30-37. https://doi. org/10.1007/978-3-642-82275-9_5

Phillips R, Silk J, Croxall J et al (2004) Accuracy of geolocation estimates for flying seabirds. Mar Ecol Prog Ser 266:265-272 
Pollet IL, Leonard ML, O’Driscoll NJ et al (2017) Relationships between blood mercury levels, reproduction, and return rate in a small seabird. Ecotoxicology 26:97-103. https://doi.org/10.1007/s10646016-1745-4

Pon JPS, Beltrame O, Marcovecchio J et al (2011) Trace metals (Cd, Cr, $\mathrm{Cu}, \mathrm{Fe}, \mathrm{Ni}, \mathrm{Pb}$, and $\mathrm{Zn}$ ) in feathers of Black-browed Albatross Thalassarche melanophrys attending the Patagonian Shelf. Mar Environ Res 72:40-45. https://doi.org/10.1016/j.marenvres.2011. 04.004

Ponchon A, Cornulier T, Hedd A et al (2019) Effect of breeding performance on the distribution and activity budgets of a predominantly resident population of black-browed albatrosses. Ecol Evol 9:87028713. https://doi.org/10.1002/ece3.5416

Preeti JKR, Thakur M, Suman M, Kumar R (2018) Consequences of pollution in wildlife: a review. Pharma Innov J 7:94-102

R Core Team (2019) R: A language and environment for statistical computing. R Foundation for Statistical Computing, Vienna, Austria. URL https://www.R-project.org/

Rainbow PS (2018) Trace metals in the environment and living organisms: the British Isles as a case study. Cambridge University Press

Revenga JE, Campbell LM, Arribére MA, Guevara SR (2012) Arsenic, cobalt and chromium food web biodilution in a Patagonia mountain lake. Ecotoxicol Environ Saf 81:1-10

Rosenblatt AE, Heithaus MR (2013) Slow isotope turnover rates and low discrimination values in the American alligator: implications for interpretation of ectotherm stable isotope data. Physiol Biochem Zool 86:137-148. https://doi.org/10.1086/668295

Sánchez-Virosta P, Espín S, García-Fernández AJ, Eeva T (2015) A review on exposure and effects of arsenic in passerine birds. Sci Total Environ 512-513:506-525. https://doi.org/10.1016/j. scitotenv.2015.01.069

Santos IR, Silva-Filho EV, Schaefer C et al (2006) Baseline mercury and zinc concentrations in terrestrial and coastal organisms of Admiralty Bay, Antarctica. Environ Pollut 140:304-311. https://doi.org/10. 1016/j.envpol.2005.07.007

Santosa SJ, Wada S, Tanaka S (1994) Distribution and cycle of arsenic compounds in the ocean. Appl Organomet Chem 8:273-283. https:// doi.org/10.1002/aoc.590080319

Scheuhammer AM (1987) The chronic toxicity of aluminium, cadimiun, mercury, and lead in birds: a review. Environ Pollut 46:263-295

Schlesinger WH, Klein EM, Vengosh A (2017) Global biogeochemical cycle of vanadium. PNAS:e11092-e11100. https://doi.org/10.1073/ pnas. 1715500114

Senesi GS, Baldassarre G, Senesi N, Radina B (1999) Trace element inputs into soils by anthropogenic activities and implications for human health. Chemosphere 39:343-377

Signa G, Calizza E, Costantini ML et al (2019) Horizontal and vertical food web structure drives trace element trophic transfer in Terra Nova Bay, Antarctica. Environ Pollut 246:772-781. https://doi. org/10.1016/j.envpol.2018.12.071

Sontag PT, Steinberg DK, Reinfelder JR (2019) Patterns of total mercury and methylmercury bioaccumulation in Antarctic krill (Euphausia superba) along the West Antarctic Peninsula. Sci Total Environ 688: 174-183. https://doi.org/10.1016/j.scitotenv.2019.06.176

Stewart R, Grosell M, Buchwalter D et al (2010) Bioaccumulation and trophic transfer of selenium. In: Ecol Assess Selenium Aquat Environ. Society of Environmental Toxicology and Chemistry, Florida, pp 93-140

Taggart MA, Figuerola J, Green AJ et al (2006) After the Aznalcóllar mine spill: arsenic, zinc, selenium, lead and copper levels in the livers and bones of five waterfowl species. Environ Res 100:349361. https://doi.org/10.1016/j.envres.2005.07.009

Taleuzzaman M (2018) Limit of blank (LOB), limit of detection (LOD), and limit of quantification (LOQ). Org Med Chem IJ 7:555722. https://doi.org/10.19080/OMCIJ.2018.07.555722

Tartu S, Bustamante P, Angelier F et al (2016) Mercury exposure, stress and prolactin secretion in an Arctic seabird: an experimental study. Funct Ecol 30:596-604. https://doi.org/10.1111/ 1365-2435.12534

Tavares S, Xavier JC, Phillips RA et al (2013) Influence of age, sex and breeding status on mercury accumulation patterns in the wandering albatross Diomedea exulans. Environ Pollut 181:315-320. https:// doi.org/10.1016/j.envpol.2013.06.032

Thompson KR (1992) Quantitative analysis of the use of discards from squid trawlers by black-browed albatrosses Diornedea rnelanophris in the vicinity of the Falkland Islands. Ibis (Lond 1859) 134:11-21

Wakefield ED, Phillips RA, Belchier M (2012) Foraging black-browed albatrosses target waters overlaying moraine banks - A consequence of upward benthic-pelagic coupling? Antarct Sci 24:269-280. https://doi.org/10.1017/S0954102012000132

Westerlund S, Ghman P (1991) Cadmium, copper, cobalt, nickel, lead, and zinc in the water column of the Weddell Sea , Antarctica. Geochim Cosmochim Acta 55:2127-2146

Whitney MC, Cristol DA (2017) Impacts of sublethal mercury exposure on birds: a detailed review. Rev Environ Contam Toxicol 244:113163. https://doi.org/10.1007/398

Wilson HM, Petersen MR, Troy D (2004) Concentrations of metals and trace elements in blood of spectacled and king eiders in northern Alaska, USA. Environ Toxicol Chem 23:408-414. https://doi.org/ 10.1897/03-21

Wolfaardt A (2013) An assessment of the population trends and conservation status of black-browed albatrosses in the Falkland Islands. In: First meeting of the population and conservation status working group of the agreement on the conservation of albatrosses and petrels. La Rochelle, France, 29-30 April 2013. PCSWG1 Doc 14

Wolfe MF, Schwarzbach S, Sulaiman RA (1998) Effects of mercury on wildlife: A comprehensive review. Environ Toxicol Chem 17:146160

Yang DY, Chen YW, Gunn JM, Belzile N (2008) Selenium and mercury in organisms: Interactions and mechanisms. Environ Rev 16:71-92. https://doi.org/10.1139/A08-001

Yildirim D, Sasmaz A (2017) Phytoremediation of As, Ag, and $\mathrm{Pb}$ in contaminated soils using terrestrial plants grown on Gumuskoy mining area (Kutahya Turkey). J Geochem Explor 182:228-234. https:// doi.org/10.1016/j.gexplo.2016.11.005

Zanden MJV, Clayton MK, Moody EK et al (2015) Stable isotope turnover and half-life in animal tissues: a literature synthesis. PLoS One 10:1-16. https://doi.org/10.1371/journal.pone.0116182

Zhang Y, Jaeglé L, Thompson LA (2014) Natural biogeochemical cycle of mercury in a global three-dimensional ocean tracer model. Glob Biogeochem Cycles 28:553-570. https://doi.org/10.1111/14622920.13280

Zwolak I (2020) The role of selenium in arsenic and cadmium toxicity: an updated review of scientific literature. Biol Trace Elem Res 193:44 63. https://doi.org/10.1007/s12011-019-01691-w

Publisher's note Springer Nature remains neutral with regard to jurisdictional claims in published maps and institutional affiliations. 